\title{
COMPOUNDING STERILE PREPARATIONS FOR INTENSIVE CARE UNIT PATIENTS (ICU) IN ONE PRIVATE HOSPITAL IN SEMARANG
}

\section{PERACIKAN SEDIAAN STERIL UNTUK PASIEN INTENSIVE CARE UNIT (ICU) DI SALAH SATU RUMAH SAKIT SWASTA DI SEMARANG}

\author{
Sara Septi Widayani*), Sri Hartati Yuliani, Dina Christin Ayuning Putri
}

Faculty of Pharmacy, Universitas Sanata Dharma, Campus 3 Paingan, Maguwoharjo, Depok, Sleman, Yogyakarta 55282, Indonesia

Received April 9, 2018; Accepted November 16, 2018

\begin{abstract}
Sterile preparations for intravenous injection probably cause greater risk of errors than other preparation treatment routes due to their complex preparation steps. Errors in preparation and compounding stage will affect the quality and stability of the pharmaceutical product obtained. The aim of this study was to evaluate the process of compounding and assess both quality and stability of the parenteral preparations products that resulted from the compounding process for ICU's patients in one private hospital in Semarang, Central Java, Indonesia. This observational analytic study was conducted using accidental sampling technique. The descriptive study results showed that sterile preparation in hospital " $X$ " was not performed according to the Guidelines for Drug Injection and Handling of Cytostatic Preparations. In order to evaluate the quality of the sterile preparations, three different drugs with the highest prevalence of use: namely ceftriaxone, meropenem and omeprazole were evaluated. It was found that the $\mathrm{pH}$ value of omeprazole was not acceptable due to the use of an appropriateness solvent. The sterility tests showed that the preparation products prepared by the nurses were free from microorganisms. Keywords: dispensing errors, intensive care unit, intravenous preparations, patient, sterile compounding

ABSTRAK

Pemberian obat secara intravena memiliki resiko kesalahan yang lebih besar dibandingkan dengan rute pengobatan lain karena tahap preparasi dan peracikan yang lebih kompleks. Kesalahan pada preparasi dan peracikan akan berpengaruh pada kualitas hingga stabilitas sediaan parenteral yang diracik. Tujuan dari penelitian ini adalah mengevaluasi proses peracikan, kualitas serta stabilitas sediaan parenteral yang dihasilkan dari proses peracikan untuk pasien Intensive Care Unit (ICU) salah satu rumah sakit swasta (RS “ $X$ ”) di Semarang. Penelitian ini merupakan penelitian observasional analitik dengan teknik pengambilan data secara accidental sampling. Subyek penelitian terbagi menjadi dua macam yaitu subyek penelitian deskriptif dan subyek penelitian analitik. Hasil deskriptif menunjukan preparasi hingga peracikan yang dilakukan di ICU RS " $X$ " belum dilakukan sesuai Pedoman Pencampuran Obat Suntik dan Penanganan Sediaan Sitostatik. Kualitas sediaan racikan yang dievaluasi adalah tiga macam obat dengan prevalensi penggunaan tertinggi yakni; ceftriaxone, meropenem dan omeprazole. Pengujian menunjukan terdapat perbedaan nilai pH sediaan injeksi omeprazol yang diracik di rumah sakit karena penggunaan pelarut yang tidak tepat. Hasil uji bebas kuman menunjukkan pada sediaan yang diracik tidak terdapat pertumbuhan mikroorgannisme.
\end{abstract}

Kata kunci: dispensing error, intensive care unit, sediaan parenteral, pasien, peracikan sediaan steril

*Corresponding author: Sara Septi Widayani

Email: s.septi.widayani@gmail.com 


\section{INTRODUCTION}

Parenteral preparations are described as preparations intended for injection, infusion or implants in the body. Parenteral administration has several benefits such as its fast onset and effect, avoiding the first pass effect, predictability of drug amount in the blood, avoiding the drug degradation in the gastrointestinal system, and its possibility to treat an emergency and unconscious patients (Shargel et al., 2005).

It is should be considered that parenteral administration of drugs may have higher risk of medication errors compared to other administration routes. The complex steps during preparation, compounding, storage, and administration lead to the possibility of medication errors. Several drugs which are unstable in the form of solution need to be reconstituted before administration due to their solid form. Dose adjustment should be done for several drugs to provide specific medication dose for patients. The possibility of medication errors is becoming more important since the stricter requirement of drug carriers and the toxicity issues for several parenteral administration drugs (Agoes, 2009).

According to the Indonesian Ministry of Health (2009; 2009) sterile preparations compounding should be done by pharmacists at the Pharmacy Installation. Sterile preparations compounding requires special techniques with a background in knowledge of sterility, physicochemical properties, drug stability, drug incompatibility and the risk of dangerous exposure to drugs such as for antibiotics (Nguyen et al., 2015). In addition, special facilities and infrastructure are needed to support the whole compounding work to achieve the sterility and drug stability.

Previous studies have been conducted to evaluate the compounding process of sterile preparations compared to the Guideline for I.V. Admixture and Handling Cytostatic and Basic Guidelines of Sterile Dispensing (Ministry of Health of the Republic of Indonesia, 2009; Ministry of Health of the Republic of Indonesia., 2009). The studies showed that some critical aspects in sterile preparations did not meet the requirements according to the guidelines, such as personnel, facilities, infrastructures and aseptic process (Putri and Yuliani, 2018; Sudianto et al., 2018).

Previous research in order to assess the compatibility of intravenous drugs for ICU patients has been conducted in a hospital in
Surabaya. The results showed that $30.16 \%$ of sterile preparations compounding were done without considering the compatibility of the drug compounded (Dwijayanti et al., 2016). Research related to compatibility evaluation also concluded that incompatibility of sterile preparations was one of the real problems that occurred in patients' medication in the ICU. The percentage of occurrences for incompatibility incidents were reported in the range of $0.30 \%$ to $18.70 \%$ (Fahimi et al., 2008). A systematic review study conducted by Salmasi et al. (2015) found that the common errors that occur during preparation handled by pharmacists and nurses in Malaysia and Vietnam were wrong techniques and wrong solvent types. A study conducted by Ong and Subasyimi (2013) at Selayang Hospital Malaysia showed that there were 341 errors identified from 349 preparations and administration stages. Research conducted by Strbova et al. (2015) found that unclear drug labels increase the risk of medication errors. Hence, it is necessary to assess the conformity of the procedures for parenteral preparations compounding.

Research related to the compounding of sterile preparations in the ICU has never been done at the hospital where the data was collected. The aim of this study was to evaluate the compounding process as well as assess the quality and stability of the parenteral preparations for ICU's patient in one of the private hospitals in Semarang, Cental Java, Indonesia. The results from this study will be useful in order to improve the pharmaceutical care implementation in the hospital.

\section{METHODS}

\section{Study design}

This research was a non-experimental study with descriptive and analytical design conducted by observing prospectively a type $\mathrm{C}$ private hospital in Semarang with the research permission number of 748.2/RSX/LP/DIKLAT/ VIII/2017. Data collection was done every Saturday and Sunday during September to October 2017 with accidental sampling technique. The independent variables in the descriptive study were the personnel, compounding process, and the results of sterile preparations, while the dependent variables were the conformity according to the Guideline for I.V. Admixture and Handling Cytostatic (Ministry of Health of the Republic of Indonesia., 2009).

Analytical study was conducted at the Pharmacy Laboratory of Universitas Sanata Dharma in October 2017 with a purposive 
sampling technique. The independent variable in this study was the process of compounding the preparation, while the dependent variables were $\mathrm{pH}$ and the presence or absence of microbial growth.

\section{Instrumentations}

The research instrument used in this descriptive study was a set of observational sheets according to the Guideline for I.V. Admixture and Handling Cytostatic and Basic Guidelines of Sterile Dispensing (Ministry of Health of the Republic of Indonesia, 2009). The instrument used for analytic study was a $\mathrm{pH}$ meter.

The observational sheet includes several aspects as follows: 1) facilities, infrastructure and supporting system (including compounding personnel, compounded sterile rooms, laminar air flow, pass boxes, special waste bags); 2) compounding preliminaries (including right patient, right medication, right dosage, right route, right administration time, checking the drug name, checking product expiration date, checking product batch number, accuracy of solvent / diluent, accuracy of the amount of solvent); 3) compounding process (including washing hands before compounding work, use gloves and masks, hand disinfection, ampule/vial disinfection before opened, sample transfer techniques, use of singleuse needles); and 4) results of sterile preparations (clarity, stability, labelling, complete information on label).

\section{Observation}

Observation data were collected by observing the preparation process and compounding process of sterile preparations. The inclusion criteria of the study subjects were compounding parenteral preparations for the "X" Hospital ICU patients done during the observation period. All samples that met the inclusion criteria for conformity were immediately evaluated for compounding errors during the compounding preliminaries and process of parenteral preparations according to the guidelines. In this study, there were no exclusion criteria because all existing samples were evaluated.

\section{Test of Sterile Preparation Quality}

Quality evaluation of sterile preparations was done on all samples which met the inclusion criteria. The inclusion criteria were defined as the three drugs with the highest frequency of use for ICU patients in Hospital "X" based on observations. The three drugs were formulated twice (duplo); one sample was formulated based on the compounding procedure in the hospital with the worst case condition (worst case criteria based on observations), while one other sample was formulated according to the Guideline for I.V. Admixture and Handling Cytostatic and Basic Guidelines of Sterile Dispensing (Ministry of Health of the Republic of Indonesia, 2009). Analytical data collection was done by measuring the $\mathrm{pH}$ suitability using a $\mathrm{pH}$ meter. The germ-free test was done at the Semarang Health Center by inoculating samples of sterile preparation into a universal medium for bacteria, then observing the presence or absence of microbial growth.

\section{Data analysis}

Data analysis was done by verifying the observations listed in the Observational Sheet with the reference literature used, Guideline for I.V. Admixture and Handling Cytostatic and Basic Guidelines of Sterile Dispensing. Analysis of observation data was done by calculating the percentage form of errors in each aspect using the equation:

$\%$ nonconformity $=\frac{\text { number of nonconformity }}{\text { total of observation sample }} \times 100 \%$

If the result for $\%$ nonconformity is $0 \%$, it can be concluded that the aspect in compounding preliminaries and process was meeting the requirements as mentioned in the Guideline for I.V. Admixture and Handling Cytostatic and Basic Guidelines of Sterile Dispensing.

\section{RESULTS AND DISCUSSION}

Observations were conducted for 25 patients in ICU consisting of 24 adult patients and 1 pediatric patient. During the observation, 119 sterile preparations were provided (Figure 1). The results showed that sterile preparations with highest frequently prepared were omeprazole injection, meropenem injection, and ceftriaxone injections.

Critically-ill patients have high potential of getting stress-related mucosal disease (SRMD). Omeprazole is a proton pump inhibitor (PPI). It is an effective agent to decrease gastric acid secretion. Omeprazole is often used with critically ill patients because it is more effective than histamine 2 receptor antagonists in preventing clinically important and overt upper gastrointestinal bleeding (Alhazzani et al., 2013; Barkun et al., 2012). It can explain why omeprazole injection was the most frequently prepared in ICU. 


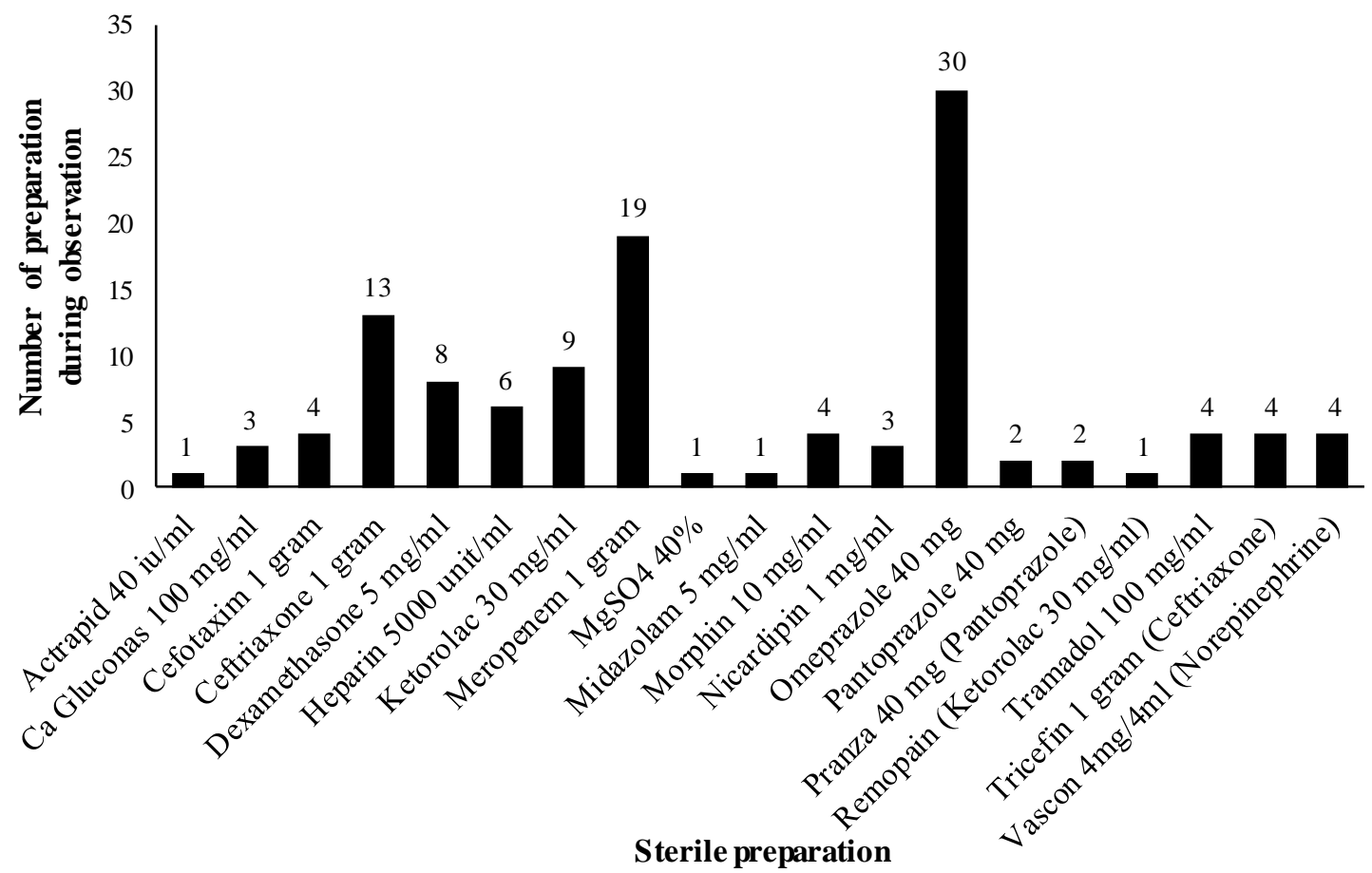

Figure 1. Sterile preparation during observation

Infections are common in patients in contemporary ICUs, and risk of infection increases with duration of ICU stay so that they get antibiotics (Vincent et al., 2009). Meropenem and Ceftriaxone are in the family of $\beta$-lactam type of antibiotics. Both are frequently used in ICUs for severe infection or to prevent another infection (Wong et al., 2014). Ceftriaxone is a well tolerated third generation cephalosporin with a broad spectrum activity against gram positive and gram negative bacteria, commonly used in intensive care units (ICU) for the empirical or documented treatment of a wide range of infections, such as pulmonary, urinary, intra abdominal and central nervous system infections (Garot et al., 2011). Meropenem has a good potential to prevent nosocomial infection from becoming worse and as therapy for bacteremia conditions (Trisnadewi and Widodo, 2014). It also explains why these two antibiotics were commonly used for ICU patients.

\section{Facilities, Infrastructure and Supporting System}

The observation results for Facilities, Infrastructure and Supporting System are shown in Table I. Regulations in Indonesia state that compounding of sterile preparations is under the responsibility of a certified pharmacist in the Hospital(Ministry of Health of the Republic of
Indonesia, 2016; Ministry of Health of the Republic of Indonesia., 2009; Ministry of Health of the Republic of Indonesia, 2009; Webster, 2015). Compounding of sterile preparations for ICU patients in Hospital X were done by nurses. The lack of the pharmacist's role in compounding sterile preparations in the ICU is due to the limited number of pharmacists with overloaded duty for pharmacy service in the hospital.

The process of preliminaries and compounding of sterile preparations must be done by personnel/staff who have been trained under the responsibility and supervision of pharmacists in Hospital Pharmacy Installation because Pharmacists have the knowledge and skills in dispensing drugs, both in terms of mixing techniques, related to aspects of sterility, and to the stability aspects of the sterile preparation. If indeed compounding cannot be done by pharmacists, then the short-term solution that can be done is by increasing the capacity of personnel in the field of sterile preparations as continuing education activities for hospital health workers to improve patient services as a form of Pharmaceutical Care and Interprofessional Education (Maharani et al., 2013; Putri and Yuliani, 2018).

Facilities and infrastructure for compounding sterile preparations in the ICU of Hospital " $X$ " did not conform to the guidelines. In the Hospital " $\mathrm{X}$ " 
compounding parenteral preparations for ICU patients were done in the ward, where there were no sterile rooms or special equipment to support the compounding process. The nurse performs a compounding process on the table that is used to mix parenteral and non-parenteral preparations. Before compounding sterile preparation, the nurses have to make sure that table is clean and there are no ingredients other than those used for compounding. The table is placed in the nurse's room next to the administration desk and doctor's table. The compounding process is carried out without Laminar Air Flow (LAF), without completing the compounding document and does not include medical devices used for compounding, labeling, and drugs that will be mixed or compounded into a sterile space through a pass box.

Based on the Basic Guidelines for Dispensing Sterile Preparations, compounding sterile preparations should be done in a sterile room, in LAF. All tools and material that are needed should be taken to a sterile room via a pass box. If there are no sterile room facilities and LAF, the shortterm solution for compounding parenteral preparations can be carried out in special conditions by paying attention to various aspects such as the compounding space used must be clean, separate and special for sterile preparations only because the procedure performed must be aseptic. Special tables that are routinely cleaned and sterilized can be used instead of LAF for short term solutions.

Table I. Results of the descriptive study on several aspects $(n=119)$

\begin{tabular}{|c|c|}
\hline Aspects & $\begin{array}{l}\text { Nonconformity } \\
(\%)\end{array}$ \\
\hline \multicolumn{2}{|l|}{ Facilities, infrastructure and supporting system } \\
\hline Conducted by pharmacist & 100.00 \\
\hline Sterile room availability & 100.00 \\
\hline LAF availability & 100.00 \\
\hline Pass box availability & 100.00 \\
\hline Special waste bag availability & 0 \\
\hline \multicolumn{2}{|l|}{ Compounding preliminaries } \\
\hline $\begin{array}{l}\text { Right patient, right medication, right dosage, right route, right } \\
\text { administration time }\end{array}$ & 0 \\
\hline Checking the drug name & 0 \\
\hline Checking product expiration date & 0 \\
\hline Checking product batch number & 100.00 \\
\hline Appropriateness of solvent & 25.21 \\
\hline Solvent volume accuracy & 32.77 \\
\hline \multicolumn{2}{|l|}{ Compounding process } \\
\hline Washing hands before compounding work & 33.00 \\
\hline Usage of gloves and masks & 100.00 \\
\hline Hand disinfection & 0 \\
\hline Ampule/vial disinfection before opened & 31.09 \\
\hline Sample transfer techniques & 0 \\
\hline Usage of single-use needles & 0 \\
\hline \multicolumn{2}{|l|}{ Result of sterile preparations } \\
\hline Clarity & 10.08 \\
\hline Stability & 2.52 \\
\hline Labelling & 0 \\
\hline Complete information on label & 0 \\
\hline
\end{tabular}

Table II. pH evaluation of sterile preparation

\begin{tabular}{clccc} 
No. & Sterile preparation & Theoretical $\mathrm{pH}$ & $\mathrm{pH}$ sample A & $\mathrm{pH}$ sample B \\
\hline 1. & Ceftriaxone 1 gram & $6-8$ & 6.5 & 6.4 \\
2. & Meropenem 1 gram & $7.3-8.3$ & 7.5 & 7.7 \\
3. & Omeprazole 40 mg & $8.8-10$ & 8.3 & 8.6 \\
\hline
\end{tabular}

Note:

Sample A is sterile preparation compounded in Hospital X with worst case

Sample B is sterile preparation compounded based on Basic Guidance of Sterile Dispensing 
Special waste bags for sterile preparations are needed to prevent accident. Sterile preparation involving the use of syringes and ampules are categorized as risk or hazardous waste (Amin et al., 2013; Chartier, 2014). All of the sterile preparation waste in ICU Hospital X have been separated from general waste. There were some special bags to collect the hazardous waste.

\section{Compounding preliminaries}

Compounding preliminaries involve a number of activities, including checking that the patient's name, drug, dosage, route and administration time is correct, product's expired date, and product's batch number. Other important steps to do are calculating dosage suitability, using appropriate solvents, calculating solvent volume, making labels and completing compounding documents to prevent medication errors that can harm patients (Cousins et al., 2005).

Conformity profile of preliminaries phase before compounding sterile preparations in ICU in Hospital X is shown in Table I. Personnel who performed preliminaries had checked the patient, medications, dosage, route, administration time, and product's expired date before they compounded. This is a good practice that must be maintained to reduce the risk of medication errors. Meanwhile, the batch number of the drug were not checked even once. The batch number of the product must be observed and recorded in the compounding document as an archive, so that if one day medication error is found that arose in the preparation caused by the initial product it can be traced and reported to the manufacturer (Collins, 2014).

A total of $25.21 \%$ of drugs were done using appropriateness solvents (compared with solvent in Handbook of Injectable Drugs). In ICU Hospital $\mathrm{X}$, most of the sterile preparations (Figure 1) were formulated or reconstituted with Aqua Pro Injection and given through a syringe pump, except ketorolac and tramadol preparations that were using $0.9 \% \mathrm{NaCl}$ as a solvent and given by i.v. drip. There are limited information about incompatibility of some product with several solvents (Dwijayanti et al., 2016; Kanji et al., 2010). This gap becomes a difficulty in assessing the potential incompatibility of a drug with a solvent. The safest way that can be done is to use solvents that have been known to be compatible with the drug based on several trusted literature such as the current Handbook of Injectable Drugs (FASHP, 2012).
A total of $32.77 \%$ of drugs were dissolved with inaccuracies in volume of solvent (compared with volume suggested in brochure). The main guideline used to see the volume of drug solvents is the drug packaging leaflet. If there is no information how much the volume of solvents recommended in the drug packaging leaflet, the researchers recommend other guidelines such as the Handbook on Injectable Drugs 16th Edition (FASHP, 2012) or the Guideline for I.V. Admixture and Handling Cytostatic (Ministry of Health of the Republic of Indonesia., 2009).

An example of the inaccuracy volume of solvent that was observed is the compounding of ceftriaxone injection. The leaflet states that each 1 gram of ceftriaxone powder for injection is dissolved with $10 \mathrm{~mL}$ of water for injection. At the time of observation, ceftriaxone reconstitution was done with a variety of solvent volumes: $5 \mathrm{~mL}, 8$ $\mathrm{mL}$; up to $20 \mathrm{~mL}$. The difference in the amount of solvent can affect the solubility rate of ceftriaxone injection in solvents and the tonicity of the solution (Putri and Yuliani, 2018).

\section{Compounding Process}

The observation results show that some aseptic techniques were not implemented well in ICU Hospital X (Table I). Implementation of aseptic techniques must be carried out in compounding sterile preparations. One procedure that must be done in aseptic techniques before compound preparations is personnel must wear a complete personal protective equipment (PPE), which is done to prevent possibilities of contamination from personnel to preparations that are formulated and also prevent exposure to the drugs formulated to personnel. In addition, hand washing or hand disinfection is a mandatory activity to fulfill aseptic procedures (Ministry of Health of the Republic of Indonesia, 2009) Surprisingly, all of the compounding sterile preparations (100\%) observed were performed without wearing handscoon and mask while 33\% did not involve washing hands, although at least they have disinfected hands before compounding the sterile preparations.

If compounding were not done aseptically, it is likely that contamination will occur and can threaten patients' safety and cause medication errors (Agyemang and While, 2010). Factors that can cause nurses to not follow the procedure of aseptic techniques are high workloads or the low ability or lack of knowledge about basic guidelines in compounding sterile preparations (Keers et al., 
2015). One short-term solution that can be done is by conducting training on good compounding sterile preparations (aseptic technique), in order to improve the ability of (Maharani et al., 2013).

Aseptic techniques should be implemented to reduce risk of contamination. Right transfer technique and using single needle/syringe to collect the drug can optimize this important goal (Ministry of Health of the Republic of Indonesia, 2009). All compounding sterile preparations in ICU Hospital $\mathrm{X}$ were performed with a good transfer technique and always uses single needle/syringe.

\section{Results of sterile preparations}

The observation results of sterile preparations are shown in Table I. We found that $10.08 \%$ of sterile preparations had turbidity after being compounded and then a few moments later turbidity disappeared. It happened in ceftriaxone injections dissolved with $5 \mathrm{~mL}$. However, turbidity indicates the presence of powdered drug particles that are still visible in the solution. It can become harmful to the patients because it can cause embolism if it has not been completely dissolved when administered (Langille, 2013).

The stability of sterile preparations must also be a concern. Stability of stocks includes physical, chemical, and microbiological stability. Changes in physical stability can be identified if there is a change in color, appearance, clarity, and consistency of the preparation. Changes in chemical stability are indicated by product degradation. There are several factors that affect product degradation, such as light, metal, oxygen, water, etc. (Falconer and Steadman, 2017; Srivastava and Kumar, 2017).

The results of the observation showed that there was potential for instability that might occur as much as $2.52 \%$ in nicardipine injection preparations. According to (FASHP, 2012) nicardipin injection is one of the photosensitive drugs, but in ICU Hospital X, nicardipin injections were not protected from light, while in the storage instructions printed on the label, it states it must be kept away from direct light. The possibility that can occur if photosensitive preparations exposed to light is a decrease in stability. One short-term solution that possibly can be done according to the Guideline for I.V. Admixture and Handling Cytostatic (Ministry of Health of the Republic of Indonesia, 2009) is to protect the solution using aluminum foil or black bags to protect photosensitive drugs from light.
Sterile preparations should be labelled after compounded. Right labelling can prevent medication error (Merali et al., 2008). In ICU Hospital $X$, the sterile preparation were not labelled after compounded, which means that there was no information about the products. The reason from the personnel is because the sterile preparations were directly administered to patients and the hospital did not provide labels for the sterile preparations.

Standard labels for sterile preparations in Guideline for I.V. Admixture and Handling Cytostatic (Ministry of Health of the Republic of Indonesia, 2009) should contain important information such as: Patient's name, medical report number, room, drug, concentration/dose, administration route, compounding date and time, beyond use date, storage procedure. One short term solution that can possibly be done is providing labels for sterile preparations. Preprinted or peel-off flag labels on ampules and vials can facilitate correct labelling (Merry et al., 2011).

\section{Physical quality of sterile preparations}

Physical quality tests were done on 3 drugs with the highest frequency of use, i.e. Ceftriaxone 1 gram, Meropenem 1 gram and Omeprazole 40 mg. Evaluations carried out included $\mathrm{pH}$ test and germ free test. Evaluation was done on sterile preparations compounded by following the Basic Guidance of Sterile Dispensing and sterile preparations compounded by the hospital based on the worst conditions observed, i.e. not using PPE, not washing hands, and done at the nurse's desk.

An important component that must be considered in dispensing sterile preparations is the $\mathrm{pH}$ of the compounded drugs which will have an impact on incompatibility (Newton, 2009). The $\mathrm{pH}$ test was done on two groups of test subjects and the results are listed in Table II. Chemical incompatibility describes the chemical degradation of one or more drugs compounded, causing therapeutic toxicity or inactivation. Degradation is not always observable. Specific $\mathrm{pH}$ values or a narrow range of $\mathrm{pH}$ values are needed to maintain drug stability after being mixed (Newton, 2009).

The $\mathrm{pH}$ of Sample A and Sample B for Ceftriaxone 1 gram and Meropenem 1 gram that was dissolved in water for injection, conformed with theoretical $\mathrm{pH}$. Meanwhile $\mathrm{pH}$ of Sample A Omeprazole injection had a $\mathrm{pH}$ below theoretical $\mathrm{pH}$. It possibly happened because omeprazole in ICU Hospital X was dissolved using water for injection instead of the appropriate solvent provided from the manufacturer. It is especially 
important to always use the right solvent to get the right $\mathrm{pH}$.

A germ-free test was conducted on samples produced from compounding in the ICU Hospital "X". Sterile means that the preparation meets the criteria free of microorganisms, pathogens and particles. In this study, the researchers defined the term, sterile is to be free of germs or microorganisms and proved by testing in the laboratory of Semarang Health Center. The test results show that the preparations produced from Hospital X are germ-free. It might happen because two of the samples tested are antibiotics while the process of inoculating samples to universal media was done without inactivating the ability to inhibit bacteria. In addition, other factors that can be influential are the products might contain preservatives, so microorganisms cannot contaminate them (Pramanick et al., 2013).

\section{CONCLUSIONS}

Based on the research conducted, it can be concluded that the compounding process carried out for patients in the Intensive Care Unit " $\mathrm{X}$ " Hospital is largely not in accordance with the Guidelines for Compounding Syringes and Cytostatic Treatment. The quality of 3 sterile preparations was free of bacterial growth. The $\mathrm{pH}$ measured of Ceftriaxone and Meropenem was still in the $\mathrm{pH}$ range based on the literature. Meanwhile $\mathrm{pH}$ of Omeprazole injection that was dissolved using appropriateness solvent had a $\mathrm{pH}$ below theoretical $\mathrm{pH}$. It is especially important to always implement The Guideline for I.V. Admixture and Handling Cytostatic and The Basic Guidelines of Sterile Dispensing to prevent medication errors that can harm the patient.

\section{ACKNOWLEDGEMENT}

The research was funded by the LPPM of Sanata Dharma University with contract number 070/Penel/LPPM-USD/IV/2017.

\section{REFERENCES}

Agoes, G., 2009. Sediaan Farmasi Steril. Penerbit ITB, Bandung.

Agyemang, R.E.O., While, A., 2010. Medication errors: types, causes and impact on nursing practice. British Journal of Nursing, 19(6), 380-385.

Alhazzani, W., Alenezi, F., Jaeschke, R.Z., Moayyedi, P., Cook, D.J., 2013. Proton Pump Inhibitors Versus Histamine 2 Receptor Antagonists for Stress Ulcer Prophylaxis in Critically Ill Patients: A
Systematic Review and Meta-Analysis. Critical Care Medicine, 41(3), 693.

Amin, R., Gul, R., Mehrab, A., 2013. Hospital Waste Management. Professional Medical Journal, 20(6), 988-994.

Barkun, A.N., Bardou, M., Pham, C.Q.D., Martel, M., 2012. Proton Pump Inhibitors vs. Histamine 2 Receptor Antagonists for Stress-Related Mucosal Bleeding Prophylaxis in Critically Ill Patients: A Meta-Analysis. The American Journal of Gastroenterology, 107(4), 507-520.

Chartier, Y., 2014. Safe Management of Wastes from Health-care Activities. World Health Organization.

Collins, S., 2014. Preparation is critical to highrisk sterile compounding. Pharmacy Today, 20(7), 8.

Cousins, D.H., Sabatier, B., Begue, D., Schmitt, C., Hoppe-Tichy, T., 2005. Medication errors in intravenous drug preparation and administration: a multicentre audit in the UK, Germany and France. BMJ Quality \& Safety, 14(3), 190-195.

Dwijayanti, S., Irawati, S., Setiawan, E., 2016. Profil Kompatibilitas Sediaan Obat Intravena dengan Pelarut pada Pasien Intensive Care Unit. Jurnal Farmasi Klinik Indonesia, 5(2), 84-97.

Fahimi, F., Ariapanah, P., Faizi, M., Shafaghi, B., Namdar, R., Ardakani, M.T., 2008. Errors in preparation and administration of intravenous medications in the intensive care unit of a teaching hospital: an observational study. Australian critical care, 21(2), 110 116.

Falconer, J.R., Steadman, K.J., 2017. Extemporaneously compounded medicines. Australian Prescriber, 40(1), 5-8.

FASHP, L.A.T., 2012. Handbook on Injectable Drugs, 17th Edition, 17 edition. ed. Amer Soc of Health System, Bethesda, Md.

Garot, D., Respaud, R., Lanotte, P., Simon, N., Mercier, E., Ehrmann, S., Perrotin, D., Dequin, P.-F., Guellec, C.L., 2011. Population pharmacokinetics of ceftriaxone in critically ill septic patients: a reappraisal. British Journal of Clinical Pharmacology, 72(5), 758-767.

Kanji, S., Lam, J., Johanson, C., Singh, A., Goddard, R., Fairbairn, J., Lloyd, T., Monsour, D., Kakal, J., 2010. Systematic review of physical and chemical compatibility of commonly used medications administered by continuous 
infusion in intensive care units. Critical care medicine, 38(9), 1890-1898.

Keers, R.N., Williams, S.D., Cooke, J., Ashcroft, D.M., 2015. Understanding the causes of intravenous medication administration errors in hospitals: a qualitative critical incident study. BMJ open, 5(3), e005948.

Langille, S.E., 2013. Particulate matter in injectable drug products. PDA Journal Of Pharmaceutical Science and Technology, 67(3), 186-200.

Maharani, L., Achmad, A., Utami, E.D., 2013. Pengaruh Edukasi Apoteker Terhadap Sikap dan Pengetahuan Perawat tentang Pencampuran Sediaan Parenteral. Jurnal Keperawatan Soedirman, 8(2).

Merali, R., Orser, B.A., Leeksma, A., Lingard, S., Belo, S., Hyland, S., 2008. Medication safety in the operating room: teaming up to improve patient safety. Healthcare Quarterly (Toronto, Ont.), 11(3 Spec No.), 54-57.

Merry, A.F., Shipp, D.H., Lowinger, J.S., 2011. The contribution of labelling to safe medication administration in anaesthetic practice. Best Practice \& Research Clinical Anaesthesiology, Safety in Anaesthesia 25(2), 145-159.

Ministry of Health of the Republic of Indonesia, 2016. Standard of Pharmaceutical Care in Hospital.

Ministry of Health of the Republic of Indonesia, 2009. Basic Guidelines for Sterile Dispensing.

Ministry of Health of the Republic of Indonesia., 2009. Guideline for i.v. Admixture and Handling Cytostatic.

Newton, D.W., 2009. Drug incompatibility chemistry. American Journal of HealthSystem Pharmacy, 66(4), 348-357.

Nguyen, H.T., Nguyen, T.D., van den Heuvel, E.R., Haaijer-Ruskamp, F.M., Taxis, K., 2015. Medication Errors in Vietnamese Hospitals: Prevalence, Potential Outcome and Associated Factors. PloS One, 10(9), e0138284.

Ong, W.M., Subasyini, S., 2013. Medication errors in intravenous drug preparation and administration. Medical Journal of Malaysia, 68(1), 52-57.

Pramanick, S., Singodia, D., Chandel, V., 2013. Excipient selection in parenteral formulation development. Pharma Times, 45(3), 65-77.
Putri, D.C.A., Yuliani, S.H., 2018. Evaluasi Peracikan Injeksi Seftriakson di Salah Satu Rumah Sakit Swasta di Semarang. Indonesian Journal of Clinical Pharmacy, 7(3), 143-153.

Salmasi, S., Khan, T.M., Hong, Y.H., Ming, L.C., Wong, T.W., 2015. Medication errors in the Southeast Asian countries: A systematic review. PLoS One, 10(9), e0136545.

Shargel, L., Yu, A., Wu, S., 2005. Biofarmasetika dan Farmakokinetika Terapan Edisi kedua. Airlangga University Press, Surabaya.

Srivastava, R.K., Kumar, S.S., 2017. An updated review: forced degradation study. World Journal of Pharmaceutical Sciences, 6(6), 709-26.

Strbova, P., Mackova, S., Miksova, Z., Urbanek, K., 2015. Medication errors in intravenous drug preparation and administration: a brief review. Journal of Nursing and Care, 4(285), 2167-1168.

Sudianto, M., Putri, D.C.A., Yuliani, S.H., 2018. Evaluation of Compounding Sterile Preparations for Hospitalized Pediatric Patients in "X" Hospital Semarang City, Indonesia. Jurnal Manajemen dan Pelayanan Farmasi (Journal of Management and Pharmacy Practice), 8(3).

Trisnadewi, I.G.A., Widodo, A.D.W., 2014. Analysis of Antibiotic Usage in Patients With Bacteremia in The ICU Unit of Dr. Soetomo Hospital Surabaya 50(4), 8.

Vincent, J.L., Rello, J., Marshall, J., Silva, E., Anzueto, A., Martin, C.D., Moreno, R., Lipman, J., Gomersall, C., Sakr, Y., Reinhart, K., Investigators, for the E.I.G. of, 2009. International Study of the Prevalence and Outcomes of Infection in Intensive Care Units. JAMA, 302(21), 2323-2329.

Webster, D., 2015. Sterile compounding: Pharmacy profess ion should take back control. Pharmacy Today, 21(3), 7.

Wong, G., Brinkman, A., Benefield, R.J., Carlier, M., De Waele, J.J., El Helali, N., Frey, O., Harbarth, S., Huttner, A., McWhinney, B., Misset, B., Pea, F., Preisenberger, J., Roberts, M.S., Robertson, T.A., Roehr, A., Sime, F.B., Taccone, F.S., Ungerer, J.P.J., Lipman, J., Roberts, J.A., 2014. An international, multicentre survey of $\beta$-lactam antibiotic therapeutic drug monitoring practice in intensive care units. Journal of Antimicrobial Chemotherapy, 69(5), 14161423. 